\title{
A New Species of Meliosma (Sabiaceae) from Southeastern Brazil and Notes on the Genus
}

\author{
Julio Antonio Lombardi \\ Departamento de Botânica, Instituto de Biociências, Universidade Estadual Paulista (UNESP), \\ Av. 24-A 1515, 13506-900, Rio Claro, São Paulo, Brazil. cissus@rc.unesp.br
}

\begin{abstract}
Meliosma chartacea Lombardi (Sabiaceae), a new species from southeastern Brazil, is described from Minas Gerais and Espírito Santo. It is characterized by its entire internal petals, very short petiole (generally less than $1 \mathrm{~cm}$ ), brochidodromous venation, and entire leaf margin. A key to determine the species from southeastern Brazil is presented. Lectotypes and new synonyms are proposed for formerly described Brazilian species: M. sellowii Urban and $M$. itatiaiae Urban.
\end{abstract}

Resumo. Meliosma chartacea Lombardi (Sabiaceae), uma nova espécie sudeste do Brasil é descrita para Minas Gerais e Espírito Santo, esta espécie é caracterizada pelas pétalas internas inteiras, pecíolos muito curtos (geralmente com menos do que $1 \mathrm{~cm}$ ), venação broquidódroma e pela margem inteira das folhas. É apresentada uma chave para a determinação das espécies do sudeste do Brasil. Lectótipos e novos sinônimos são propostos para as espécies brasileiras anteriormente descritas: $M$. sellowii Urban e $M$. itatiaiae Urban.

Key words: Brazil, IUCN Red List, Meliosma, Sabiaceae, South America.

The Sabiaceae (including the Meliosmaceae) currently include three genera and between 80 and 90 species (Arbeláez, 2004; Aymard \& Cuello, 2005) distributed in the tropical and subtropical areas of Asia and the Americas (Kubitzki, 2004). Two genera occur in the Neotropics: Ophiocaryon Endlicher, restricted to the rainforests of northeastern South America (Barneby, 1972; Aymard \& Cuello, 2005; Aymard C. \& Daly, 2006), and Meliosma Blume, an amphi-Pacific genus disjunct between Southeast Asia and tropical America, and found mostly south of Central America and in the tropical Andes.

Meliosma is traditionally subdivided into two subgenera, Meliosma and Kingsboroughia (Liebermann) Beusekom (Van Beusekom, 1971). The former includes sections Meliosma and Lorenzanea (Liebermann) Beusekom, while the latter is divided into sections Kingsboroughia and Hendersonia Beusekom. All Neotropical species are included in section
Lorenzanea, except $M$. alba (Schlechtendal) Walpers, disjunct between southern Mexico and southeastern Asia, which is placed in section Kingsboroughia (Van Beusekom, 1971).

The most recent taxonomic study of the genus, although incomplete, was by Van Beusekom (1971), who revised all the taxa of the genus with the exception of the exclusively American section Lorenzanea. He recognized 15 species in the three sections and suggested the unstudied American section would not exceed 10 species.

The most recent treatment of Neotropical Meliosma was carried out by Urban (1900), who described 17 species: 11 from Mexico, Central America, and the Caribbean islands; one from Colombia; and five from Brazil. Since then, 40 additional new species from South America have been described (Kuhlmann, 1935; Lasser, 1943; Cuatrecasas, 1949, 1955, 1959, 1988; Steyermark, 1952, 1953, 1966; Cuatrecasas \& Idrobo, 1955, 1988; Steyermark \& Maguire, 1967; Gentry, 1986, 1992; Idrobo, 1988; Steyermark \& Gentry, 1992; Aymard C. \& Cuello A., 1994; Arbeláez, 2004; Cornejo \& Bonifaz, 2006), but only one new species has been described from Brazil; this species is restricted to the Amazon Basin (Kuhlmann, 1935).

This increase in species number is attributed to the common local endemism that occurs in the family (Arbeláez, 2004) and is reported by Van Beusekom (1971) as a consequence of the pollination mechanism of the minute flowers, which eject the pollen on the thecae in a single burst at anthesis. This probably entails a great rate of geitonogamy and consequently the establishment of local morphological variations (Van Beusekom, 1971).

The small number of new taxa described from Brazil is certainly due to insufficient collections, which is partially justified by the difficulty of collecting flowering specimens (Arbeláez, 2004) and the absence of taxonomists working on this family in Brazil. As shown by the floristic surveys in other South American countries (Cuatrecasas \& Idrobo, 1955; Steyermark \& Gentry, 1992; Arbeláez, 2004), additional botanical exploration always reveals many unknown species. 
While starting a revisionary study of the family for Brazil, a very preliminary look at the meager collections deposited in principal herbaria in southeastern Brazil has revealed several undescribed Meliosma species, clearly distinct from those described by Urban $(1895,1900)$. Of these new species, thus far only one has sufficient specimens to allow a proper description, which is presented here.

Meliosma chartacea Lombardi, sp. nov. TYPE: BRAZIL. Minas Gerais: Santa Maria do Salto, Faz. Duas Barras, $16^{\circ} 24^{\prime} 12.1-29.5^{\prime \prime} \mathrm{S}$, $40^{\circ} 02^{\prime} 36.6-33.7^{\prime \prime} \mathrm{W}, \quad 760-850 \mathrm{~m}, 25$ Aug. 2003, J. A. Lombardi 5537, J. R. Stehmann, R. C. Mota \& L. G. Temponi (holotype, BHCB; isotypes, HRCB, MO). Figures 1, 2.

Haec species Meliosmae itatiaiae Urban quoad laminam foliarem magnam chartaceam spathulatam et petiolum interdum ad pulvinum redactum similis, sed ab ea foliis marginibus integris venatione brochidodroma et petalis internis apice integris differt.

Trees, treelets, or shrubs, 5-20 m tall; branches subterete, shiny, furrowed, lenticellate, soon corky, shoot apex puberulous, with very short and inconspicuous trichomes, or sparsely strigose, glabrescent; axillary buds strigose. Leaves alternate to subopposite; petioles (0.4-)0.7-1(-1.4) cm, cylindrical, swollen and pulvinus-like, drying cracked and scaly; blades (13.6-)26-31.6(-61) × (4.2-)7-10(-12.5) $\mathrm{cm}$, spatulate; base cuneate-rounded, apex acute or acuminate; margin entire, thickened by a fimbrial vein; blade chartaceous, drying brown, glabrous on both sides except for very inconspicuous and sparse short trichomes along the primary vein abaxially; venation brochidodromous, primary vein lenticellate, immersed adaxially, prominent abaxially, secondary veins flat and light brown adaxially, prominent abaxially, gradually arched toward margin, tertiary veins and veinlets very lightly prominent, sometimes light brown adaxially, flat and light brown abaxially. Inflorescence a leafy terminal or subterminal panicle, 2 to $3 \times$ branched, ca. $29-42 \times(8-) 18-28 \mathrm{~cm}$; axes lenticellate, from sparsely puberulous at base to densely puberulous at apex, glabrescent, corky on infructescence, with leafy and scale-like bracts and abortive strigose vegetative buds, branches sparsely lenticellate, densely puberulous or glabrous except at apex; leafy bracts occasional, ca. $6.2 \times 2.2 \mathrm{~cm}$, sessile or short petiolate (ca. $0.5 \mathrm{~cm}$ ), elliptic, apex acute, base rounded; scale-like bracts $0.5-3 \mathrm{~mm}$, aciculate to triangulate, strigose or sparsely pilose on the margin; pedicels absent; bracteoles 2 to $3,0.5-0.8$ $\times 0.7-1 \mathrm{~mm}$, triangular, minutely ciliate, very similar to sepals. Flower buds ca. $2 \mathrm{~mm}$ diam., spherical, green, opened flowers not seen; sepals $5,0.8-1 \times 0.8-$ $1.2 \mathrm{~mm}$, triangulate, \pm equal in size or the outer slightly smaller, carnose, ciliolate, otherwise glabrous; petals 5 , unequal, with 3 larger outer petals and 2 smaller inner ones, the outer petals oblate, cucullate, carnose, ciliolate, otherwise glabrous, outermost 1.3-1.5 × 1.1$1.6 \mathrm{~mm}$, the internal two $1.4-1.8 \times 1.3-2$; inner petals 1.4-1.5 $\times 0.4-0.5 \mathrm{~mm}$, reduced, papery, elliptic, apex acute and ciliolate; fertile stamens 2, ca. $1 \mathrm{~mm}$, opposite inner petals and adnate to ca. $1 / 4$ of their length, the filaments ligulate, incurved at apex, anthers ca. $0.7 \times$ $0.9 \mathrm{~mm}$, thecae suborbicular, transversely dehiscent before anthesis, separate and subtended by the thickened connective; staminodes 3 , ca. $1 \times 0.7 \mathrm{~mm}$, opposite to outer petals and partially adnate to them, irregular, asymmetric, with 1 or 2 hemispheric cup-like depressions in the apex, these cover the adjacent thecae of the fertile stamen while inside the bud; disk consisting of 5 vestigial teeth, $0.1-0.2 \mathrm{~mm}$; pistil $0.8-1.4 \mathrm{~mm}$, subovate, laterally flattened, 2 -locular, with 2 ovules in each locule, style $0.3-0.4 \mathrm{~mm}$, cylindrical, stigmas minute, 2-lobed. Immature (?) drupes (1.7-)2-2.3 $(-2.8) \times 1.6-1.9 \mathrm{~cm}$, asymmetric, green to light green, drying verrucose and brown, endocarp 1.4-1.7 $\times 1.5$ $1.6 \mathrm{~cm}$, subspherical, smooth, cream; seeds not seen.

Distribution, habitat, and IUCN Red List category. Meliosma chartacea is restricted to the rainforests of the Brazilian Atlantic Range and collected in five localities in the states of Minas Gerais, Espírito Santo, and São Paulo, where it occurs at altitudes of $400-850 \mathrm{~m}$. It has been reported in disturbed remnants of wet forest, on forested slopes, and along streams. This species has also been reported to occur inside different conservation areas, three in Santa Teresa Municipality, Espírito Santo-the Santa Lúcia Biological Station (ca. 440 ha.), the Augusto Ruschi Biological Reserve (3598.41 ha.), and the São Lourenço Biological Station (22 ha.) (Mendes \& Padovan, 2000); and two in São Paulo State- the Jurupará State Park (26,250 ha.) and the Serra do Mar-Núcleo Pedro de Toledo State Park (55,462 ha.). It is thus protected, at least in this part of its distribution; nonetheless, it is considered Endangered (EN) according to IUCN Red List criteria (IUCN, 2001) because its area of occurrence is less than $5000 \mathrm{~km}^{2}$, it is known to occur only at five locations, and a continuing decline of its area of occupancy is inferred for habitat fragmentation.

Phenology. Collected with flowers in August, December, and January, and with fruits from March to May and July to October.

Etymology. The specific epithet of this species refers to the chartaceous texture of its leaves. 
A
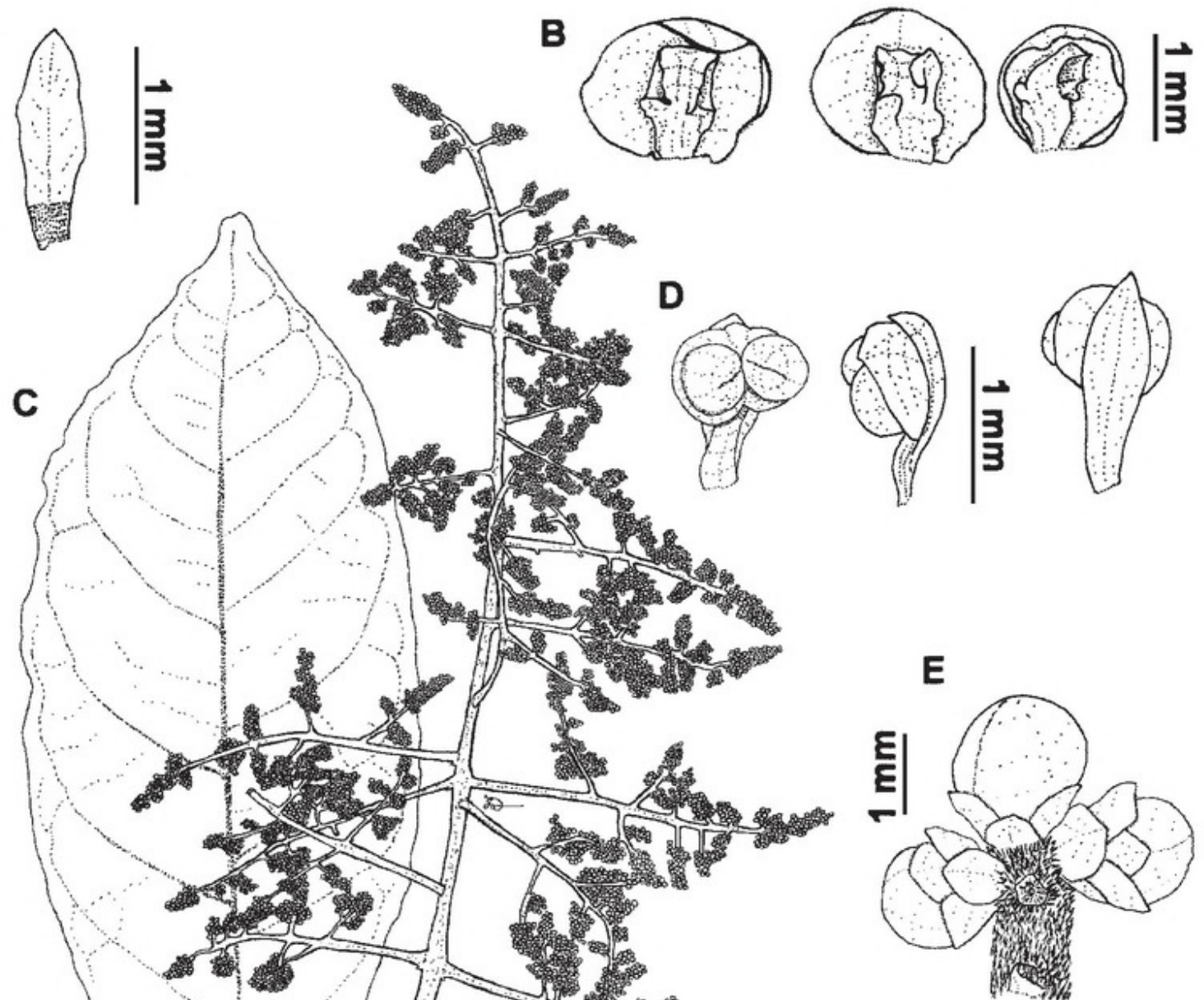

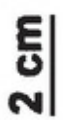

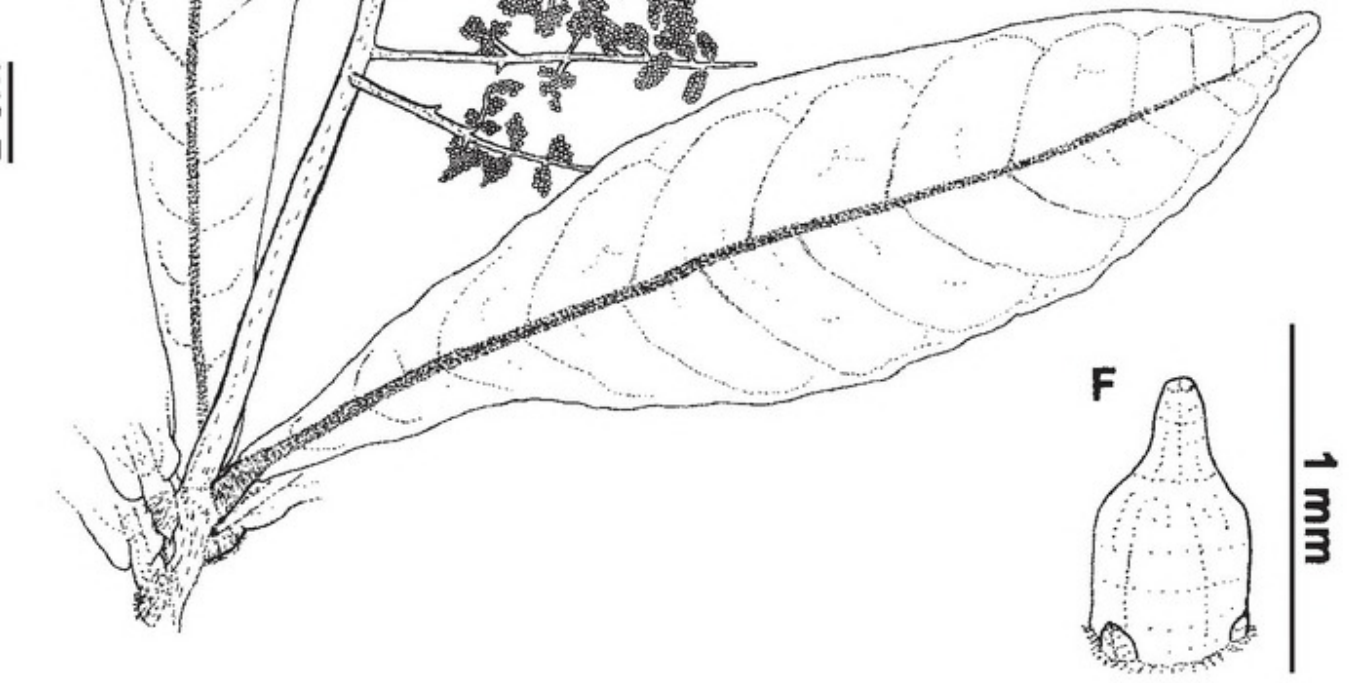

Figure 1. Meliosma chartacea Lombardi. - A. Inner petal. - B. Outer petals with adnate staminodes. —C. Branch with leaves and inflorescence. - D. Stamen with adnate inner petal: ventral, lateral, and dorsal views. -E. Apex of inflorescence branch with flower buds and subjacent bracteoles, one bud missing. - F. Pistil with two teeth of the disc. Drawn by the author from the holotype Lombardi 5537 (BHCB). 


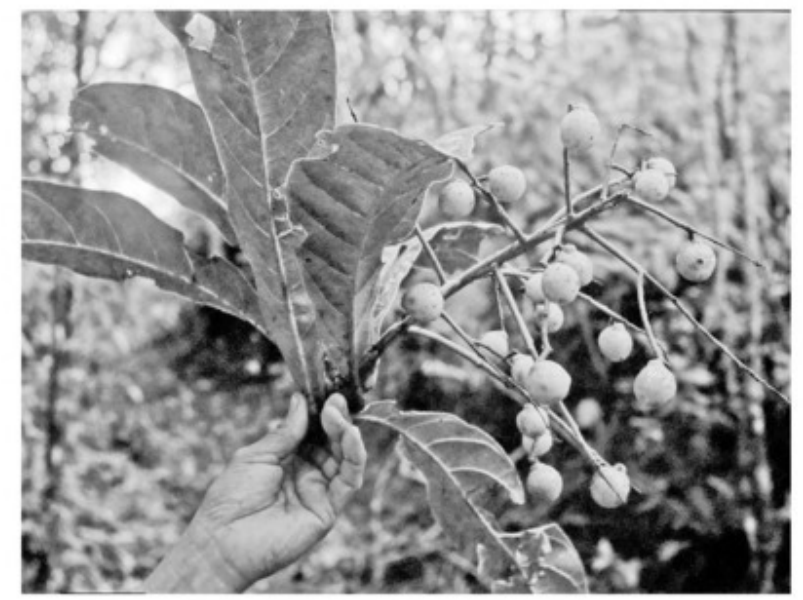

Figure 2. Meliosma chartacea Lombardi showing immature fruits. Photo by the author from the holotype Lombardi 5537 (BHCB).

\section{Vernacular. Unknown.}

Discussion. Meliosma chartacea resembles M. itatiaiae because of its large spatulate and shortpetiolate leaves. Nevertheless, M. itatiaiae has conspicuous serrate leaf margins (vs. entire margin in $M$. chartacea), semicraspedodromous venation (vs. brochidodromous), and a bifid inner petal (vs. entire).

The "disk" is composed of five reduced teeth at the ovary base. It was seen in mature buds from the holotype, but was not observed in the flowered paratypes with younger buds. In some specimens of Meliosma sellowii, the disc was not found in bud, while in others it was more or less defined. Although, herein, this structure receives the name it is given in the literature (Urban 1895, 1900; Van Beusekom, 1971), some doubts remain about its nature and possible functions in the flower, if any at all, because of the absence of anatomical and developmental studies.

The specimens collected in Santa Teresa, Espírito Santo; in Santa Maria do Salto, Minas Gerais; and in Ibiúna, São Paulo, showed different flowering periods (December-January in the first, and August for the other two). These discrepancies could be the result of insufficient sampling or may reflect a real variation of phenology. The fruits apparently remain on the plant for a long time (Fig. 2). No variation in fruit color was observed in the two different collections of the species by the author, and no other coloration is reported in the collection labels of the paratypes.

Paratypes. BRAZIL. Espírito Santo: Santa Teresa, 30 Jan. 1986, W. Boone 1068 (HRCB, MBML); Santa Teresa, Nova Lombardia, Res. Biol. Augusto Ruschi, 11 Dec. 2001, L. Kollmann 5183 (HRCB, MBML); Santa Teresa, São Lourenço, Mata Fria, 2 Dec. 1998, L. Kollmann 1167 (HRCB, MBML); Santa Teresa, São Lourenço, Est. Biol. de São Lourenço, 21 Aug. 2001, L. Kollmann 4383 (HRCB,
MBML); Santa Teresa, Est. Biol. de Santa Lúcia, 19 July 1984, W. Boone 262 (HRCB, MBML); 24 Mar. 1988, H. Q. Boudet-Fernandes 2439 (HRCB, MBML); 30 Mar. 1999, L. Kollmann 2322 (HRCB, MBML); 26 May 1999, Lopes 749 (HRCB, MBML); 28 Aug. 1993, L. D. Thomaz 962 (MBML); 19 Apr. 1994, L. D. Thomaz 1664 (MBML); 27 July 1993, $L$. D. Thomaz 1823 (MBML, Herbarium of the Universidade Federal do Espírito Santo). Minas Gerais: Santa Maria do Salto, Fazenda Duas Barras, ca. $16^{\circ} 24^{\prime} \mathrm{S}, 40^{\circ} 03^{\prime} \mathrm{W}, 10$ Mar. 2004, J. A. Lombardi 5972 (BHCB). São Paulo: Ibiúna, Parque Est. de Jurupará, caminho da Faz. Tucano, 11 Aug. 1995, O. T. Aguilar \& J. A. Pastore (SPSF); Miracatu, Parque Est. de Jurupará, estrada do Mono, 6 Sep. 1995, J. B. Baitello \& 0. T. Aguilar 805 (SPF, SPSF); Peruíbe, Parque Est. da Serra do Mar, Núcleo Pedro de Toledo, trilha do Rio do Ouro, 13 Mar. 2005, R. Cielo-Filho 378 (HRCB, SPSF).

Key to the Described Species of Meloosma in Southeastern BRAZIL

1a. Leaves spatulate, large, (13.6-)26-31.6(-61) $\times$ $(4.2-) 7-14.5(-20.5) \mathrm{cm}$, petiole relatively short, sometimes swollen and without distinct pulvinate and canaliculate parts.

2a. Inner petals bifid, lobes divergent, conspicuous, venation semicraspedodromous, leaf margin conspicuously serrate......... itatiaiae

$2 \mathrm{~b}$. Inner petals entire, venation brochidodromous, leaf margin entire ........M. chartacea

1b. Leaves elliptic to obovate, (2.9-)3.5-15.7(-21.2) $\times$ (0.9-)1.6-5.4.(-6.1) cm, conspicuously petiolated, petiole having distinct pulvinate and canaliculate parts . . . . . . . . . . . . . . . sellowii

\section{Nomenclatural Notes}

Meliosma itatiaiae Urban, Symb. Antill. 1(3): 510. 1900. TYPE: Brazil. Minas Gerais: Itatiaia, Fazenda do Taquaral, 26 Sep. 1874, Glaziou 7565 (lectotype, designated here, $\mathrm{P}$ [3 sheets, 2 of these pictured in the same F 35982]; duplicates, F [fragm.], K).

Discussion. The holotype of Meliosma itatiaiae, pictured in F 13375, was destroyed in the Botanical Museum Berlin-Dahlem Herbarium (B) (Hiepko, 1987), and the name therefore requires lectotypification. The proposed lectotype was chosen because it is more complete and the three sheets are clearly part of the same gathering, including cauline large leaves on one sheet and inflorescence parts on the other two, so that the three sheets comprise the lectotype (cf. Art. 8.3 of the International Code of Botanical Nomenclature [McNeill et al., 2006]).

Meliosma itatiaiae has been reported in the Mantiqueira Range, on the border between Rio de Janeiro, Minas Gerais, and São Paulo states. The only collection outside this range (Igaratá) is only ca. $150 \mathrm{~km}$ south from the range outskirts.

Selected specimens examined. BRAZIL. Rio de Janeiro: Engenheiro Passos, Hatschbach 45530 (US); Itatiaia, Altamiro \& Walter 139 (RB), Campos Porto 821 (RB), Glaziou 
6697 (K, P), Kuhlmann s.n. (RB 258917), Silveira s.n. (RB 2233); Rezende, Martinelli 3258 (K, NY). São Paulo: Piquete, Arzola \& Sene 703 (SPSF); Santa Isabel, Igaratá, $M$. Kuhlmann 2550 (SP), M. Kuhlmann s.n. (SP 36290), M. Kuhlmann s.n. (SP 66057).

Meliosma sellowii Urban, Ber. Deutsch. Bot. Ges. 13: 212. 1895. TYPE: Brazil. s. loc., Sellow 2205 c. 2217 (holotype, B not seen [image seen; another sheet was destroyed = F 13377]; isotype, $\mathrm{K}$ ).

Meliosma sinuata Urban, Ber. Deutsch. Bot. Ges. 13: 212. 1895. TYPE: Brazil. Rio de Janeiro: prope Petrópolis, 20 Nov. 1887, Glaziou 16707 (lectotype, designated here, $\mathrm{P}$; isotype, $\mathrm{K}$ ).

Meliosma brasiliensis Urban, Ber. Deutsch. Bot. Ges. 13: 216. 1895. TYPE: Brazil. Rio de Janeiro: Alto Macahé, 1500 m, 23 Nov. 1888, Glaziou 17729 (lectotype, designated here, P [F 35984]; duplicates, F [fragm.], P, US).

Meliosma glaziovii Urban, Symb. Antill. 1(3): 508. 1900. TYPE: Brazil. Rio de Janeiro: entre Nova Friburgo et le Alto [Macahé], 9 Oct. 1890, Glaziou 12131 (lectotype, designated here, P [F 35983]; duplicates, F [fragm.], K, $\mathrm{P}, \mathrm{US})$.

Discussion. The holotype of Meliosma sinuata (pictured in F 13378), the syntypes of $M$. brasiliensis (Glaziou 17729 [F 13372] and Glaziou 8099), and the syntypes of M. glaziovii (Glaziou 12131 [F 13374] and Glaziou 19587) were destroyed in the Botanical Museum Berlin-Dahlem Herbarium (B) (Hiepko, 1987), and the names therefore require lectotypification.

For lectotypification of Meliosma brasiliensis, the isosyntype Glaziou 8099 (Rio de Janeiro, Corcovado, Cova da Onça, 23 Nov. 1875 [F, K, P]) was also considered, but Glaziou 17729 was chosen as the more complete specimen. Likewise, for lectotypification of M. glaziovii, the isosyntype Glaziou 19587 (Alto Macahé, 5 Oct. 1891 [K, P]) was considered, but Glaziou 12131 was selected as more representative.

All the species described by Urban $(1895,1900)$ and here proposed as synonyms of Meliosma sellowii present slight variations of leaf shape and margin, indument, and inner petal apex. Intermediate states of these characteristics were seen in the many specimens collected in Santa Teresa, Espírito Santo State; Camanducaia, Minas Gerais State; and in the other localities represented by unique collections. Among the available names by priority, $M$. sellowii was the chosen name. It is the most frequently seen name on herbarium labels and in floristic and phytosociological studies (e.g., Jung-Mendaçolli, 1996; Kurtz \& Araújo, 2000; Jurinitz \& Jarenkow, 2003; França \& Stehmann, 2004).

Selected specimens examined. BRAZIL. Espírito Santo: Santa Teresa, Est. Biol. de Santa Lúcia, Bausen 21 (HRCB,
MBML); Domingos Martins, Hatschbach \& Silva 48663 (CEPEC, MBM, NY, US). Minas Gerais: Camanducaia, França 222 (BHCB, HRCB). Paraná: Antonina, Hatschbach 72720 (BHCB, MBM); Castro, Klein \& Leite 12023 (RB); Guaratuba, J. M. Silva \& Saldanha 1776 (BHCB, MBM); Morretes, J. M. Silva 1212 (BHCB, MBM). Rio de Janeiro: Pedra do Cônego, à Nova Friburgo, Glaziou 12401 (P [F 13374]); Rio de Janeiro, Kuhlmann s.n. (RB 24391); Cachoeiras de Macacu, Kurtz s.n. (RB 328374). Santa Catarina: Ibirama, L. B. Smith \& Klein 7543 (F, K, NY, P, RB, US); Porto União, Klein \& Smith 10827 (M); Rio do Sul, Reitz \& Klein 7307 (K, M, NY, US). São Paulo: Cananéia, Ilha do Cardoso, Castro 16 (HRCB); Sete Barras, Parque Est. de Carlos Botelho, Farias et al. 707 (BHCB, ESA); Jundiaí, Res. Biol. Mun. da Serra do Japi, Lombardi 6468 (HRCB); Pariquera-Açu, Udulutsch et al. 2613 (HRCB).

Acknowledgments. The author thanks Tarciso S. Filgueiras for the Latin diagnosis; Robert Vogt for the type image from the Herbarium of the Botanischer Garten und Botanisches Museum Berlin-Dahlem; Odile Poncy and Alain Changy for the type image from the Herbier National de Paris, Muséum National d'Histoire Naturelle; the reviewers Douglas C. Daly and Gerardo Aymard C. for suggestions and comments that greatly improved the manuscript; and Conselho Nacional de Desenvolvimento Científico e Tecnológico $(\mathrm{CNPq})$ for financial support (no. 471341/20061) and a research fellowship (no. 306395/2006-1). I also thank the curators of the herbaria BHCB, BM, CEPEC, HRCB, K, M, MBML, MO, NY, P, RB, and US for permission to examine the specimens or specimen loans.

\section{Literature Cited}

Arbeláez, A. L. 2004. Two new species of Meliosma (Sabiaceae) from Bolivia. Novon 14: 12-16.

Aymard C., G. \& N. Cuello A. 1994. Meliosma gentryi Aymard \& Cuello (Sabiaceae) una nueva especie para la flora de la Guayana venezolana. BioLlania 10: 1-3.

- \& 2005. Sabiaceae. Pp. 39-43 in P. E. Berry, K. Yatskievych \& B. K. Holst (editors), Flora of the Venezuelan Guayana, Vol. 9. Missouri Botanical Garden Press, St. Louis.

\& D. C. Daly. 2006. Two new species of Ophiocaryon (Sabiaceae) from South America. Brittonia 58: 270-276.

Barneby, R. C. 1972. Meliosmaceae-Ophiocaryon. Mem. New York Bot. Gard. 23: 114-120.

Cornejo, X. \& C. Bonifaz. 2006. Meliosma stellata, una nueva especie de Sabiaceae de Ecuador. Novon 16: 328-330.

Cuatrecasas, J. 1949. Studies in South American plants, I. Lloydia 11: 185-225.

- 1955. Taxonomic notes on neotropical trees. Trop. Woods 101: 10-28.

- 1959. Studies in South American plants, V. Brittonia 11: 163-172. 1988. Miscellaneous notes on neotropical flora,

XVII. New species of Meliosma. Phytologia 64: 489-494. \& J. M. Idrobo. 1955. El genero Meliosma en Colombia. Caldasia 7(33): 187-211.

— \& 1988. Tres nuevas especies de Meliosma Blume (Sabiaceae) de Colombia. Ernstia 49: 8-14. 
França, G. S. \& J. R. Stehmann. 2004. Composição florística e estrutura do componente arbóreo de uma floresta altimontana no município de Camanducaia, Minas Gerais, Brasil. Rev. Brasil. Bot. 27: 19-30.

Gentry, A. H. 1986. New Neotropical species of Meliosma (Sabiaceae). Ann. Missouri Bot. Gard. 73: 820-824. . 1992. Four new species of Meliosma (Sabiaceae) from Peru. Novon 2: 155-158.

Hiepko, P. 1987. The collections of the Botanical Museum Berlin-Dahlem (B) and their history. Englera 7: 219252.

Idrobo, J. M. 1988. Una Sabiaceae nueva de la flora de Mutis. Mutisia 72: 1-3.

IUCN. 2001. IUCN Red List Categories and Criteria, Version 3.1. Prepared by the IUCN Species Survival Commission. IUCN, Gland, Switzerland, and Cambridge, United Kingdom.

Jung-Mendaçolli, S. L. 1996. Sabiaceae. Pp. 47-48 in M. M. R. F. Melo, F. Barros, S. A. C. Chiea, M. Kirizawa, S. L. Jung-Mendaçolli \& M. G. L. Wanderley (editors), Flora Fanerogâmica da Ilha do Cardoso, Vol. 4. Instituto de Botânica, São Paulo.

Jurinitz, C. F. \& J. A. Jarenkow. 2003. Estrutura do componente arbóreo de uma floresta estacional na Serra do Sudeste, Rio Grande do Sul, Brasil. Rev. Brasil. Bot. 26: 475-487.

Kubitzki, K. 2004. Sabiaceae. Pp. 335-336 in N. Smith, S. A. Mori, A. Henderson, D. W. Stevenson \& S. V. Heald (editors), Flowering Plants of the Neotropics. Princeton University Press, Princeton.

Kuhlmann, J. G. 1935. Novas especies botanicas da Hyléa (Amazonia) e do Rio Doce (Espirito Santo). Arq. Inst. Biol. Veg. 2: 83-89.
Kurtz, B. C. \& D. S. D. Araújo. 2000. Composição florística e estrutura do componente arbóreo de um trecho de Mata Atlântica na Estação Ecológica Estadual do Paraíso, Cachoeiras de Macacu, Rio de Janeiro, Brasil. Rodriguésia 51(78/115): 69-112.

Lasser, T. 1943. Dos arboles interesantes de la flora venezolana. Bol. Soc. Venez. Ci. Nat. 8: 233-236.

Mendes, S. L. \& M. P. Padovan. 2000. A Estação Biológica de Santa Lúcia, Santa Teresa, Espírito Santo. Bol. Mus. Biol. Mello Leitão, Nov. Sér. 11-12: 7-34.

McNeill, J., F. R. Barrie, H. M. Burdet, V. Demoulin, D. L. Hawksworth, K. Marhold, D. H. Nicolson, J. Prado, P. C. Silva, J. E. Skog, J. H. Wiersema \& N. J. Turland (editors). 2006. International Code of Botanical Nomenclature (Vienna Code). Regnum Veg. 146.

Steyermark, J. A. 1952. Contributions to the flora of Venezuela. Fieldiana 28: 243-447.

- 1953. A new Meliosma from the Colombian Andes. Bull. Torrey Bot. Club 80: 500 .

1966. Novedades de la Cordillera Costanera y los Andes. Bol. Soc. Venez. Ci. Nat. 26: 453-466.

\& A. H. Gentry. 1992. Sabiaceae. Pp. 221-267 in G, Morillo (editor), Flora de Venezuela 5(1). Instituto Botánico, Caracas.

\& B. Maguire. 1967. Botany of the Chimanta Massif, II. Mem. New York Bot. Gard. 17: 440-464.

Urban, I. 1895. Ueber die Sabiaceengattung Meliosma. Ber. Deutsch. Bot. Ges. 13: 211-222.

- 1900. Sabiaceae. Pp. 497-519 in I. Urban, Symbolae Antillarum 1(3). Fratres Borntraeger, Berlin.

Van Beusekom, C. F. 1971. Revision of Meliosma (Sabiaceae), section Lorenzanea excepted, living and fossil, geography and phylogeny. Blumea 19: 355-529. 

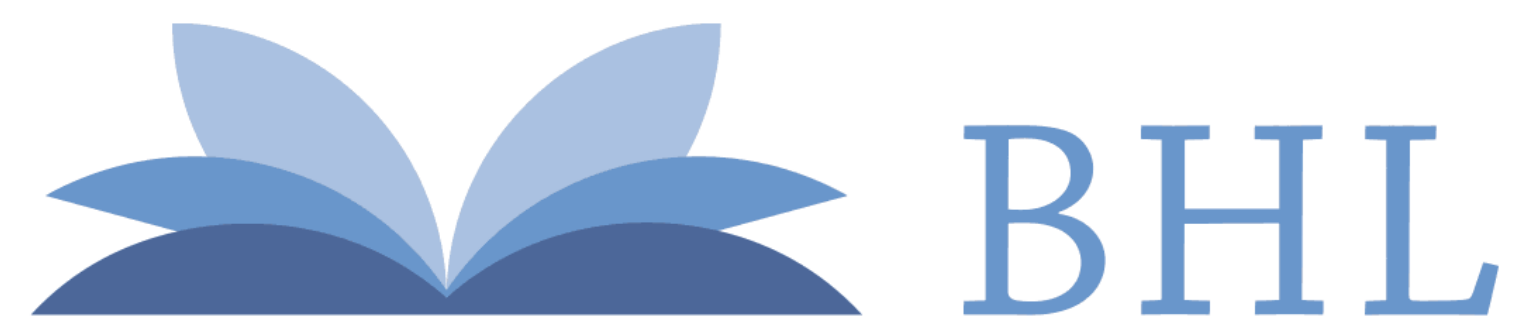

\section{Biodiversity Heritage Library}

Lombardi, Julio Antonio. 2009. "A New Species of Meliosma (Sabiaceae) from Southeastern Brazil and Notes on the Genus." Novon a journal of botanical nomenclature from the Missouri Botanical Garden 19, 62-67.

View This Item Online: https://www.biodiversitylibrary.org/item/124658

Permalink: https://www.biodiversitylibrary.org/partpdf/121879

\section{Holding Institution}

Missouri Botanical Garden, Peter H. Raven Library

\section{Sponsored by}

Missouri Botanical Garden

\section{Copyright \& Reuse}

Copyright Status: Permission to digitize granted by rights holder Rights: https://www.biodiversitylibrary.org/permissions

This document was created from content at the Biodiversity Heritage Library, the world's largest open access digital library for biodiversity literature and archives. Visit BHL at https://www.biodiversitylibrary.org. 